\title{
Effect of Educational Intervention on Knowledge and Attitudeof Nursing Students Regarding Organ Transplantation: A Pilot Study
}

\author{
Salwa A. Mohammed \\ Associate Professor, Applied Medical Science, Bishia University, KSA \\ Assist. Professor of Medical Surgical Nursing Department, Faculty of Nursing, Fayoum University, Egypt \\ Correspondence: Salwa A. Mohamed. Address: Faculty of Nursing, Fayoum University, Fayoum, Egypt. \\ Email: sam15@fayoum.edu.eg
}

\begin{abstract}
Organ donation is the donation of biological tissue or an organ of the human body from a dead or living person to a living recipient in order to save the life of the recipient. The aim of the study was to determine the effect of educational intervention on knowledge and attitude of nursing student regarding organ transplantation. Methods: A quasi experimental design with pre and posttest utilizing a convenience sample of 48 students was used to collect data using the knowledge and attitude of questionnaire. Results: showed poor knowledge about organ donation and transplantation in the pretest with a remarkable improvement and statistical significance in the posttest. Also these results showed a positive attitude toward organ donation in the pretest and posttest. Conclusion and recommendation: The study concluded that improved knowledge regarding organ donation and transplantation. The student nurses were found to have a positive attitude regarding the organ donation process after implementation of program. Future research should also focus on continuous educational programs are needed to increase awareness about organ donation in various groups in our country.
\end{abstract}

Keywords: Nurses student, knowledge, attitude, organ donation, transplantation.

\section{Introduction}

Organ transplantation provides the only opportunity for patients with end stage organs disease to have an enhanced quality of life and an extended survival. Organ transplantation is accepted as the preferred and often only treatment option for end stage organ disease [1]. Nationwide, more than 114, 24 people are waiting for lifesaving of life- enhancing organ transplant as well as one patient is added to a transplant waiting list every 10 minutes. The organs most commonly donated are the kidneys, heart, lungs, and cornea and liver, with the kidneys being the organ most frequently donated [2].Therefore, Organ donation and transplantation is aimed at saving the lives of people when they are faced with organ failure.

The organ donation and solid organ transplantation have made dramatic progress in the past 60 years. There is every reason to believe that this trajectory will continueas transplantation becomes more widespread, more nurses will encounter patients who have undergone solid organ transplantation and assist with the care of potential organ donor $[3,4]$.

Several studies over the last 15 years have focused on the learning needs, attitudes and viewpoints of undergraduate health science students in regards to donation and opt-in vs. opt-out systems [5-12]. Despite the somewhat mixed findings, there seems to be consensus on the importance of early exposure in preparing the future role models for the general public. However, in most studies the type and extent of exposure has been an educational intervention targeting a single discipline, medicine $[6,7,8]$ or nursing $[10,12]$ rather than multiple health science disciplines $[9,11]$.

A recent study of hospital donation practices and their impact on organ donation outcomes revealed gaps in knowledge of organ donation, brain death, referral criteria, and at times, a poor relationship between the hospital and organ procurement organization [13]. It is important that nurses are knowledgeable about the organ donation process. Nurse must assess their own beliefs that pertain to organ donation since the attitude of the nurse and care given to the family cane impact the outcome of organ donation. Therefore, following the studywhich examined the change of behavior through knowledge and attitude change, this study aims to lead the change in behavior through knowledge and acknowledgement improvement regarding blood and organ donation to construct healthier society [4].As medical and nurses student have vital role of promoting organ donation. However, many lack relevant basic knowledge and are influenced by personal attitudes and biases held by the general public [14-19]. Insufficient knowledge and failure to identify possible donors are considered important 
contributing factors responsible for the shortage of available organs [20-23]. There is also a discrepancybetween attitudes and actions [23-26]. Attitudes, knowledge, and actions are interrelated and previous studies showed that culture and religion were important external influences affecting the decision process. This indicates needs for organ donation vitalization, and as the knowledge regarding the organ donation is one of the significant factors in donation behavior [27]. In other words, knowledge can bring about the change in attitude [28]. Bidigare and Oermann[29] suggested that the nurse possessing positive attitudes and greater knowledge will be better able to provide comfort and support the donor's family in the decision-making process. Hence, the study aims to assess effect of educational intervention on knowledge and attitudes of nursing students, enrolled health science disciplines regarding to organ transplantation.

\section{Operational definition:}

- Knowledge:It refers to level of understanding regarding organ transplantation.

- Attitude:It refers to views or opinion of nursing students regarding organ transplantation.

- Organ donation/transplantation:Gifting a body organ to a person who is in need of that.

\section{Aim of the study:}

The aim of the study was to determine the effectiveness of educational intervention on knowledge and attitude of nursing student regarding organ transplantation.

\section{Hypothesis:}

H1: There will be a significant difference between pre-test and post-test knowledge scores regarding organ transplantation among nursing students.

H2: There will be a significant difference between pre-test and post-test practice scores regarding organ transplantation among nursing students.

H3: There will be significant association between knowledge and attitude of nursing students.

Research design: Quasi Experimental design will be used in this study

Setting of the study: This study will be conducted in college of Applied Medical Sciences Bishia Girl.

Sample:

This study involved a convenience sampling on sample on 48 nursing students; agree to participate in the study, age group between 18-25years, who are studying from level 7th. Also the students who are exposed for pervious education program about organ donation will be excluded.

Tools:

Tool consists of 3 parts:

Part 1:Demographic Data: It consists of age, sex, levels, source of information.

Part 2:Students' Knowledge Questionnaire Regarding the Organ Donation: developed by the researcher after review literature [4, 6, 29, 30] to assess nurses knowledge regarding organ donation. It consisted of 18 multiple choice questions asking about the explanation or meaning of organ donation, its signs and symptoms, the causes and risk factors failure transplantation, and the way of control and treatment of any infection and description of diet plan (type and amount) for transplant patient, importance and time of follow-up with physician, physical activity types and hygienic care. The correct answer for any knowledge item was given a score of 1, and the incorrect given zero. The scores of each area of knowledge were added and converted into a percent score.

Part 3:Structured Attitude Questionnaire Regarding the Organ Donation:developed by the researcher after review literature [31-33], to assess attitude regarding organ donation. It consisted of 14 items regarding organ transplantation attitude. Scoring for questions was true or false as follow: positive' self-rated attitude was defined as answering 'true' to the question 'I support organ donation'; negative attitude was defined answer "false". This was revised and improved for the study aiming.

Ethical considerations:

An informed consent for participation in the study was taken verbally from students after full explanation of nature, purpose, and benefits of the study.

Validity and reliability:

The developed questionnaires tools were reviewed by 5 panels of experts' medical and nursing field in order to ensure content comprehensiveness, clarity, relevance, and applicability. The test-retest reliability showed a value of 0.85

Pilot study:

A pilot study was carried out on ten percent from the total sample size (5students) to test the feasibility and clarity of the of the study tools. Required modifications were done based on the results. The time needed to fill 
in the questionnaire was about (20-30 minutes).Subjects included in the pilot study were excluded from the main study sample.

\section{Methods:}

- Approval for data collection was obtained from the responsible of college for conducting the study.

- The tools were developed by the researcher based on reviewing literature. Also, tool were tested for its content relevance by 5 experts from medical and nursing staff, the necessary modifications were made.

- A pilot study was done on 5 nursing students to test clarity and applicability of the tool, and time consuming. The necessary modifications were done to suit this study.

- Data collection for this study was taking 30 days starting on April 1st, 2016. The methods of teaching used in the program were lectures, group discussions, video, power point, as well as posters. Students were divided into 4 groups 12 students in each group. And allow for each student the chance to interact and ask questions session and give feedback.

- The education intervention will cover 3 hours per weeks for subjects. The lectures will focus on general knowledge about organ donation and also information's about universal precautions to prevent infection.

- Student Knowledge Assessment Sheet filled by researcher for pre-test and post-test for study group, to identify student nurses knowledge before and after the program, within 30-40 minutes

\section{Statistical Analysis:}

The data entry and statistical analysis were done using SPSS 18.0. Results were presented as the frequencies, percentage, paired t-test, Pearson correlation analysis to test statistical significance of some variables and to test effectiveness of the programs. Statistical significance was considered at p-value $<0.05$.

\section{Result}

Table 1.Shows that the all participants $(100 \%)$ were females, and more than half $(56 \%)$ of them were aged between 20 and 22 years old with a mean age of (20.61 23.8$)$. Also student were single, have level seven of education. The aged (years) presented in figure 1.

Table 1.Socio demographic characteristics of study

\begin{tabular}{|c|c|c|}
\hline Variables & $\mathrm{N}$ & $\%$ \\
\hline Age (years): & & \\
\hline$\bullet \quad \leq 19$ & 20 & 41.66 \\
\hline • $20-22$ & 27 & 56.25 \\
\hline$\bullet \quad>22$ & 1 & 2.08 \\
\hline Mean \pm S. D & \multicolumn{2}{|c|}{$20.61 \pm 8.3$} \\
\hline Gender: & & \\
\hline - Female & 48 & 100 \\
\hline $\begin{array}{l}\text { Level of education : } \\
\text { - } \quad \text { Seven } / \text { class } 4^{\text {th }}\end{array}$ & 48 & 100 \\
\hline $\begin{array}{l}\text { Marital status: } \\
\text { Single }\end{array}$ & 48 & 100 \\
\hline
\end{tabular}

Figure 1:

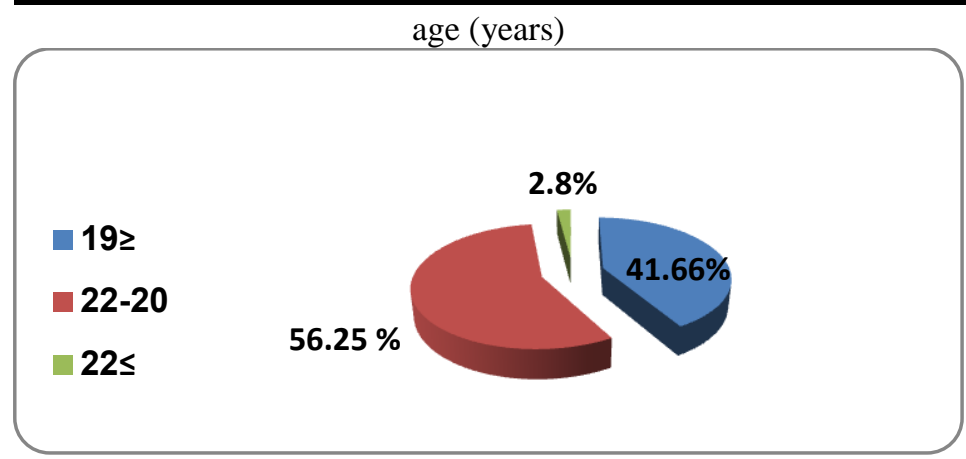

Distribution of

Table 2.Reveals that there are differences between pre and posttest percentage of knowledge as regard to definition of transplantation, reason, contraindications, type of donor, signs and symptoms of infection, test evaluation before transplantation, treatment and care, complications after transplantation and health education $(20.83 \%, 27.08 \%, 41.66 \%, 52.08 \%, 37.5 \%, 20.83 \%, 31.25 \%, 27.08 \%$ and $35.41 \%$ respectively) on pretest compared to $(93.75 \%, 91.66 \%, 95.83 \%, 100 \%, 95.83 \%, 93.75 \%, 87.5 \%, 93.75 \%$ and $91.66 \%)$ in the post test (after intervention). There is highly significant difference between pre and posttest of nurses student $(\mathrm{p}=0.00)$. Table 3.This table shown that students response to the attitudes regarding organ donation and transplantation questionnaires in the pre and posttest was statistically significant $(\mathrm{p}=0.000)$. 
Figure 2. This figure shows that (53\%) were positive attitude reported, (40\%) neutral and negative attitude only $(7 \%)$ of participants. While, improved positive attitude $(92 \%)$ and $(8 \%)$ were neutral attitude and no negative attitude was reported in the posttest. The relationship between attitude in the pre and posttest was statistically significant ( $0 \leq 0.05)$.

Table 4.This table shows that there are a positive relationship between level of knowledge and attitude score of nursing students on organ transplantation posttest, $(r=0.22)$ at $p \leq 0.05$.

Table 2.Percent distribution of nurses' student Attitude and opinions score about organ donation and transplantation

\begin{tabular}{|c|c|c|c|c|c|}
\hline \multirow[t]{2}{*}{ Items } & \multicolumn{2}{|c|}{$\begin{array}{c}\text { Before } \\
\text { Implementation }\end{array}$} & \multicolumn{2}{|c|}{$\begin{array}{c}\text { After } \\
\text { Implementation }\end{array}$} & \multirow[t]{2}{*}{$\mathbf{P}$ - value } \\
\hline & $\mathbf{N}$ & $\%$ & $\mathbf{N}$ & $\%$ & \\
\hline - Transplantation definition & 10 & 20.83 & 45 & 93.75 & $0.00 *$ \\
\hline - Reason for transplantation & 13 & 27.08 & 44 & 91.66 & $0.00^{*}$ \\
\hline - Contraindications to transplantation & 20 & 41.66 & 46 & 95.83 & $0.00^{*}$ \\
\hline - Type of donor & 25 & 52.08 & 48 & 100 & $0.00 *$ \\
\hline - Signs and symptoms of infection & 18 & 37.5 & 46 & 95.83 & $0.00^{*}$ \\
\hline - Test evaluation before transplantation & 10 & 20.83 & 45 & 93.75 & $0.00^{*}$ \\
\hline $\begin{array}{l}\text { - Treatment and care of organ } \\
\text { transplantation }\end{array}$ & 15 & 31.25 & 42 & 87.5 & $0.00^{*}$ \\
\hline - Complications after transplantation & 13 & 27.08 & 45 & 93.75 & $0.00^{*}$ \\
\hline - Health education & 17 & 35.41 & 44 & 91.66 & $0.00^{*}$ \\
\hline
\end{tabular}

Table 3: Frequencies and percentages of correct knowledge regarding organ donation and transplantation before and after implementation $(\mathrm{N}=48)$

\begin{tabular}{|c|c|c|c|c|c|}
\hline \multirow[t]{2}{*}{ Items } & \multicolumn{2}{|c|}{ Pretest } & \multicolumn{2}{|c|}{ Post test } & \multirow[t]{2}{*}{ p-value } \\
\hline & $\mathbf{N}$ & $\%$ & $\mathbf{N}$ & $\%$ & \\
\hline $\begin{array}{l}\text { 1. Not willing to receive organ/tissue of donor } \\
\text { of other religion }\end{array}$ & 30 & 64.85 & 46 & 95.83 & 0.00 \\
\hline $\begin{array}{l}\text { 2. It is possible to cure illness with organ } \\
\text { donation }\end{array}$ & 12 & 20.08 & 38 & 79.16 & 0.00 \\
\hline 3. Did religious fatwa allow organ donation & 14 & 29.16 & 39 & 81.25 & 0.01 \\
\hline 4. Organ donation insults human dignity & 20 & 41.66 & 40 & 83.33 & 0.00 \\
\hline 5. Organ transplantation saves life & 38 & 79.16 & 48 & 100 & 0.00 \\
\hline 6. Support organ donation & 39 & 81.25 & 46 & 95.83 & 0.01 \\
\hline $\begin{array}{l}\text { 7. If we donate organ after death, it will } \\
\text { prolong life of another person }\end{array}$ & 14 & 29.16 & 41 & 85.41 & 0.00 \\
\hline 8. Organ donation disturb peace of dead person & 12 & 29.16 & 39 & 81.25 & 0.00 \\
\hline $\begin{array}{l}\text { 9. Donating organ to another person after death } \\
\text { is humane }\end{array}$ & 18 & 37.5 & 40 & 83.33 & 0.00 \\
\hline 10. Do you agree with the idea organ donation & 29 & 60.41 & 48 & 100 & 0.00 \\
\hline $\begin{array}{l}\text { 11. Family members do not support the idea of } \\
\text { organ donation }\end{array}$ & 15 & 31.55 & 43 & 89.58 & 0.00 \\
\hline 12. Know someone who received an organ & 21 & 43.75 & 46 & 95.83 & 0.00 \\
\hline $\begin{array}{l}\text { 13. There is fear of } \\
\text { surgery/disfigurement/post-operative pain } \\
\text { after organ donation }\end{array}$ & 18 & 37.5 & 40 & 83.33 & 0.00 \\
\hline $\begin{array}{l}\text { 14. Physicians should have organ donation } \\
\text { information available in their office }\end{array}$ & 12 & 29.16 & 43 & 89.58 & 0.00 \\
\hline
\end{tabular}

ficant at the $\mathrm{p}<0.05$ probability level

Figure 2 .Distribution of attitude regarding organ donation and transplantation 


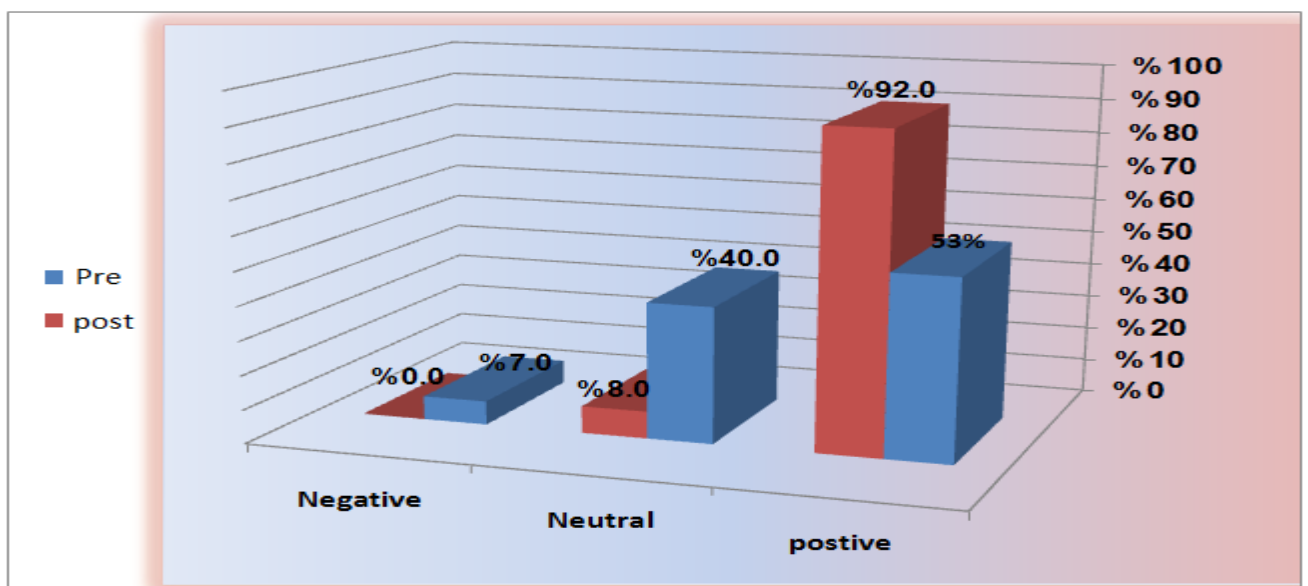

Table 4: Relationship between knowledge and attitude among study group

\begin{tabular}{|l|c|c|}
\hline \multicolumn{1}{|c|}{ Research Variable } & \multicolumn{2}{|c|}{ Knowledge score } \\
\hline Attitude & Pre & Post \\
\hline r- value & 0.14 & 0.21 \\
\hline p- value & 0.22 & $0.045^{*}$ \\
\hline
\end{tabular}

\section{Discussion:}

Organ donation and transplantation could be a miracle for the person who has lost hope for life. Nurses working on transplantation units are given in-service training and gain knowledge through experience. Nurses are in a position to inform patient and relative, and to ask families to donate organs [34]. Therefore, the aims of this study were to examine the effect of educational intervention on knowledge and attitudes regarding organ donation and transplantation at Bishia of Applied Medical Science.

The study results showed that the majority of the participants were in the age group of (20-22) in contrasts to study by Fugen et al., [35] stated that the most of study (91.4\%) were 18-24-year old. Chung et al., [36] found that the mean age of the subjects was 21 years. A further study by Gidimisana [37] stated that the majority of the participants were in the age group of 21-30.

Results of this study proven that participants knowledge wasn't sufficient in the pretest and improved post the educational intervention. This result was supported by the work of Zuhre et al.,[38] who showed that the knowledge and attitude of university students about transplantation and donation. Their results stated good knowledge after the program especially among medical students. In addition, studies worked by Collins[39], Sonmez et al., [40], and Lopez- Montesinos, [41] all noted that nurses and medical students had insufficient knowledge about the process of organ transplantation and emphasized the importance of awareness campaigns, appropriate information and curriculum content.

Other studies of medical students in different countries have shown a similar trend, where the proportion demonstrating accurate knowledge about donation cards was significantly increased after education [42]. Also, Shaheen\&Souqiyyeh, [43] indicated that the lack of training and information on organ donation and transplantation contributed to shortage of organs in Saudi Arabia., they were recommendations from this study included intensifying the training of personnel involved in organ donation in order to improve the organ donation rates and their beliefs. Therefore, this area of research needs prompt attention in their health and medical colleges.

The present study reported that the participants had poor knowledge regarding organ donation and transplantation, but about half of them reported positive attitude regarding organ donation in the pre-test and this percentage were improved in the post-test. The result was agreed with a study by Lye et al., [44] among Malaysia University students to state that the majority of the undergraduate nursing student showed a good attitude. A similar study worked by Bilgel et al., [45] who found that students had more positive attitudes toward live organ donation and transplants. Similarly, study by Kaur et al., [30] conducted among nursing students to assess their knowledge, attitude and perception regarding organ donation. They revealed that around two third students had average knowledge, $22 \%$ had good knowledge and only $3.5 \%$ student had poor knowledge regarding organ donation. Regarding attitude and perception, 55\% had neutral attitude, $43.5 \%$ had positive attitude and only $1 \%$ student had negative attitude. Another studies by Chung et al. [36] among the University of Hong Kong respectively sought to explore attitudes and knowledge towards organ donation; these revealed that the participants demonstrated positive attitudes towards organ donation, there was still a lack of knowledge about the topic, and as such public education was recommended to correct misconceptions. In contrast study by Alsaied et al., [46] found that nurses have poor attitudes towards the organ donation, as compared to technicians. This study indicated that there was a significant statistical correlation between 
knowledge and attitude among nursing students. These findings are congruent with those of Sahin and Dinc [47] who reported week correlation between knowledge and attitude among nursing students. Chung et al., [36] reported that there are discrepancies between attitude and action was also evident. Similarly, study by Kim et al., [48] proven the change of behaviour through knowledge and attitude change. In contrast study done by Azzazy and Mohamed [49] stated that knowledge could not change attitude among participants.

\section{Conclusion And Recommendations:}

The purpose of this study was to examine the effects of educational intervention on nursing students' knowledge and attitude regarding organ donation and transplantation. Results of this study revealed that majority of the students had improved knowledge regarding organ donation and transplantation. The student nurses were found to have a positive attitude regarding the organ donation process and that their attitude would be influenced by increasing their knowledge of the organ transplantation process, which play an important role in public education, about organ donation and increase the rate of organ transplantation. This study suggests the need for further research with large sample. Future research should also focus on continuous educational programs are needed to increase awareness about organ transplantation in various groups in our country.

\section{Reference}

[1] Blazek D.J, Hartley C., Lough E.M., Martel M., Shafer J.T., and Williams-Taylor S.(2016). Organ Donation and Transplantation. Chapter 37, available at:http://clinicalgate.com/organ-donation-and-transplantation-2/

[2] Rocher, M. (2010). How to become an organ donor.Fairlady. August 2010. Available: http://www.marierocher.com/resources/How\%20to\%20Organ\%20Donor\%20_FL.pdf [Accessed on 05 October 2015].

[3] Organ procurement and transplantation (2012).Network. Http://optn.transpant.hts.gov.Acessessed, May7

[4] Urden D.L., Stacy M.K., and Lough E.M.(2014). Critical care nursing: Diagnosis and management, Mosby,Inc., wiley and Sons. Pp.951-65.

[5] Stadlbauer V, Steiner P, Schweiger M, Sereinigg M, Tscheliessnigg KH, Freidl W, Stiegler P.(2013). Knowledge and attitude of ICU nurses, students and patients towards the Austrian organ donation law.BMC Med Ethics.;14:32

[6] Essman CC, Lebovitz DJ.(2005). Donation education for medical students: enhancing the link between physicians and procurement professionals. Prog Transplant.;15(2):124-8

[7] Bramstedt KA, Moolla A, Rehfield PL.(2012). Use of standardized patients to teach medical students about living organ donation.Prog Transplant.;22(1):86-90

[8] Radunz S, Juntermanns B, Heuer M, Frühauf NR, Paul A, Kaiser GM.(2012). The effect of education on the attitude of medical students towards organ donation.Ann Transplant; 17(1):140-4

[9] Manyalich M, Paredes D, Ballesté C, Menjívar A.(2010). The PIERDUB project: International Project on Education and Research in Donation at University of Barcelona: training university students about donation and transplantation. Transplant Proc.;42(1):11720

[10] Whisenant DP, Woodring B. (2012).Improving attitudes and knowledge toward organ donation among nursing students. Int $J$ NursEduc Scholarsh.;9:22

[11] Rykhoff ME, Coupland C, Dionne J, Fudge B, Gayle C, Ortner TL, Quilang K, Savu G, Sawany F, Wrobleska M.(2010). A clinical group's attempt to raise awareness of organ and tissue donation.Prog Transplant.;20(1):33-9

[12] López-Montesinos MJ, ManzaneraSaura JT, Mikla M, Ríos A, López-Navas A, Martínez-Alarcón L, Rodríguez MM, Ramírez P.(2010). Organ donation and transplantation training for future professional nurses as a health and social awareness policy.Transplant Proc. 42(1):239-42

[13] Siminoff LA.,Traino HM.(2009). Improving donation outcomes: hospital development and the rapid assessment of hospital procurement barriers in donation.Prog Transplant. 19(2):44.

[14] Burra P, De Bona M, Canova D, et al.(2005). Changing attitude to organ donation and transplantation in university students during the years of medical school in Italy. Transplant Proc;37:547-50.

[15] Laederach-Hofmann K, Gerster BI.(1998). Knowledge, attitude and reservations of medical students about organ transplantation: results of a survey during the first year of study [in German]. Schweiz Med Wochenschr;128:1840-9.

[16] Bardell T, Hunter DJ, Kent WD, Jain MK.(2003). Do medical students have the knowledge needed to maximize organ donation rates? Can J Surg;46:453-7.

[17] Afonso RC, Buttros DA, Sakabe D, et al. Future doctors and brain death: what is the prognosis? Transplant Proc.

[18] Dutra MM, Bonfim TA, Pereira IS, Figueiredo IC, Dutra AM, Lopes AA. (2004).Knowledge about transplantation and attitudes toward organ donation: a survey among medical students in northeast Brazil. Transplant Proc;36:818-20.

[19] Dhaliwal U.(2002). Enhancing eye donation rates.Training students to be motivators. Indian J Ophthalmol;50:209-

[20] Chernenko SM, Jensen L, Newburn-Cook C, Bigam DL.(2005). Organ donation and transplantation: a survey of critical care health professionals in nontransplant hospitals. Prog Transplant;15:69-77.

[21] Gaber AO, Hall G, Phillips DC, Tolley EA, Britt LG. (1990).Survey of attitudes of health care professionals toward organ donation. Transplant Proc;22:313-5.

[22] Boey KW.(2002). A cross-validation study of nurses' attitudes and commitment to organ donation in Hong Kong.Int J Nurs Stud;39:95-104

[23] Chan YM, Po-lin PL, Lee WK, Wong NH.(1997). Attitudes of Hong Kong nurses toward cadaveric organ donation. ANNA $\mathrm{J} ; 24: 413-21$

[24] Ozdag N. (2001).The nurses knowledge, awareness and acceptance of tissue-organ donation. EDTNA ERCA J.;27:201-6.

[25] Kent B., and Owens RG.(1995). Conflicting attitudes to corneal and organ donation: a study of nurses' attitudes to organ donation. Int J Nurs Stud.; 32:484-92.

[26] Radecki CM, Jaccard J. (1997).Psychological aspects of organ donation: a critical review and synthesis of individual and next-ofkin donation decisions. Health Psychol; 16:183-

[27] Jeong HS. (2013).The Review of Organ Transplantation Law and the Culture of Organ Donation. Culture Media, and Entertainment Laws ; 7(1):79-103. 
[28] Sagare SM, Bogam RR, Murarkar SK, Patil UP, andGhate MM.(2012). Knowledge, attitude and practices of ASHAs regarding tuberculosis and DOTS. Indian Journal of Science and Technology; 5(3):2401-04.

[29] Bidigare S. A., and Oermann M. H. (1991). Attitudes and knowledge of nurses regarding organ procurement.

[30] Kaur S., Ghai S.,Krishman ., Rana D.,Kathania D., Kaur G., et al., (2015). knowledge , attitude and perception regarding organ donation among the nursing students. Journal of postgraduate medicine,education and research,49(3):105-110.

[31] Dilip. S and Lingaji S.T. (2016).Knowledge and attitude of Medical Students and nurses towards Organ Donation. J Cont Med A Dent., Volume 4 Issue 1, P:58-61.

[32] Annadurai K., Mani K., and Ramasamy J. (2012). A study on knowledge, attitude and practices about organ donation among college students in Chennai, Tamil Nadu -2012.Prog Health Sci 2013, Vol 3, No2,

[33] Alsaied O., Bener1A., Al-Mosalamani Y., and Nou B.(2012). Knowledge and Attitudes of Health Care Professionals toward Organ Donation and Transplantation. Saudi J Kidney Dis Transpl., 23(6):1304-1310

[34] Ozadg N., Bal C., (2001). The nurses' knowledge, awareness and acceptance of tissue-organ donation. Available at: DOI: 10.1111/j.1755-6686.2001.tb00179.x

[35] Fugen G., Mustafa G., and Medine E. (2006). Knowledge and attitudes of medical, nursing, dentistry and health technician students towards organ donation: a pilot study. JCN. DOI: 10.1111/j.1365-2702.2006.01431.x

[36] Chung KY, Carol WK, Jacky YC, Kevin CY, Adams HY, Adams HY, Sunny PC, Joyce YM, Joyce YM, Joyce YM, Joyce YM, Kris PT, Kris PT, Kris PT, Bruce YH, and Pamela PW.( 2008). Attitudes, knowledge, and actions with regard toorgan donation among Hong Kong medical students. Hong Kong Med J 14:278-85

[37] Gidimisana N.D. (2016). Knowledge and attitudes of undergraduate nurses towards organs donation and transplantation in a selected campus of a college in the Eastern care. Master thesis, Published by the University of Cape Town

[38] Zühre, K., Gültekin, K. G., Demirtaş, O.K., Karadeniz, D. \&Çalapkulu, Y. (2015). Effects of Targeted Education for First-Year University Students on Knowledge and Attitudes about Stem Cell Transplantation and Donation. Official Journal of the Middle East for Organ Transplantation; 13(1), 76-81.

[39] Collins TJ. (2005). Organ and tissue donation: a survey of nurse's knowledge and educational needs in an adult ITU. Intensive and Critical Care Nurs 21: 226-233.

[40] Sonmez, Y., Zengin, E., Ongel, K., Kisiouglu, N. \&Ozturk, M. (2010). Attitude and behaviour related to organ donation and affecting factors: A study of last term students at a university. Transplantation Proceedings.42:1440-1452.

[41] Lopez-Montesinos, M.J. (2010). Organ donation and transplantation training for future professional nurses as a health and social awareness policy.TransplantationProceedings.42(1):239-242.

[42] Nakayama Y, Ota M, Isshiki M, Mori M.(2002). Evaluation of effects of education about a donor card on university or college students [in Japanese]. Nippon KoshuEiseiZasshi ;49:1097-106.

[43] Shaheen F. A. M. \&Souqiyyeh M. Z. (2004). Increasing organ donation rates fromMuslim donors: Lesson from a successful model. Transplantation Proceedings.36(7):1878-1880.

[44] Lye J. L., Soon L.K., Nizam W.A., Ahmad W., Tan S. C. (2015). Knowledge and Attitude about Stem Cells and Their Application in Medicine among Nursing Students in University Saints Malaysia, Malays Journal of Medical Science, 22(4), 23-31.

[45] Bilgel H., Sadikoglu G., andBilgel N..(2016). Knowledge and Attitudes about Organ Donation Among Medical Students. Transplantationsmedizin, 18.Jahrg., S. 92

[46] Alsaied O., Bener A., Al-Mosalamani Y. \&Nour B. (2012). Knowledge and attitudes of health care professionals toward organ donation and transplantation.Saudi Journal of Kidney Diseases and Transplantation.23(6):1304-1310.

[47] Sahin N. and Dinc H. (2009). Pregnant Women's Knowledge and Attitudes about Stem Cells and Cord Blood Banking.International Nursing Review, 56, 250-256.

[48] Kim MH.,Jeon HW., Chon MY.(2015). Study on the Knowledge and Attitudes of Falls and Awareness of Fall Risk Factors Among Nursing Students. Indian Journal of Science and Technology. 8(1):74-80

[49] Hend M. AzzazyM.H and Mohamed F.H.(2016). Effect of Educational Intervention on Knowledge and Attitude of Nursing Students Regarding Stem Cells Therapy.IOSR Journal of Nursing and Health Science. Volume 5, Issue 2 Ver. IV, PP 75-80.

Salwa A. Mohammed. "Effect of Educational Intervention on Knowledge and Attitude of Nursing Students Regarding Organ Transplantation: A Pilot Study." IOSR Journal of Nursing and Health Science (IOSR-JNHS) 6.4 (2017): 64-70. 